\title{
FEATURES OF PREPARATION FOR ORAL DEFENSE OF THE FINAL QUALIFYING WORK (BACHELOR'S DEGREE) IN GERMAN IN THE CONTEXT OF THE TRANSITION TO DISTANCE LEARNING
}

\author{
Irina Kruse \\ Associate Professor, RUDN University, RUSSIA, kruseirina@rambler.ru
}

\begin{abstract}
The difficult situation associated with the spread of coronavirus and the transition to distance learning has made serious adjustments to the process of preparing an oral defense in German for the final qualifying work in the chosen direction of jurisprudence at the specialized department. Training of bachelor students at the Department of Foreign Languages of the Law Institute of the Russian University of Friendship of Peoples under the program "Translator in the field of professional communication" provides, along with passing a qualification exam in the main discipline of training, oral defense in a foreign language of the final qualification work. Under the guidance of a teacher, students who have studied German for professional purposes for eight semesters prepare a presentation and a defense speech in German before the State Attestation Commission. Over the years, a strict system of preparation for this important stage in the formation of future human rights defenders has been developed, capable of professionally and reasonably using a foreign language at a level not lower than B2 to present the results of scientific research on the selected topic. Taking into account the requirements of the Federal State Educational Standard of Higher Professional Education in the field of Jurisprudence (qualification (degree) "bachelor"), graduates of the "Translator in the field of professional communication" program become competitive in the international labor market, have the skills of effective work in their specialty at the level of world standards and professional communication skills in German.
\end{abstract}

The purpose of the study of the author of this article is to study the effectiveness of using the new format of preparing students for oral defense of the final qualification work in German online and adjusting the training program itself, taking into account the transition to a new format of education.

The materials of the study were based on the survey data of students enrolled in the undergraduate program. In the course of the study, a comparative method was used. The research methodology included questionnaires and statistical data processing.

Keywords: oral defense, final qualification work, conditions for the transition to distance learning, department of foreign languages, German for professional purposes, competitiveness in the international labor market.

\section{INTRODUCTION}

The basis of communicative competence in the field of jurisprudence is the ability and skills of fluency in a foreign language, contributing to the successful solution of communication problems and self-realization of a lawyer, both professionally and personally (Europäische Komission, 2012). The final phase of the program for studying a foreign language for professional purposes under the program "Translator in the field of professional activity" at the Department of Foreign Languages of the Law Institute of the Peoples' Friendship University of Russia for many years has been preparing a speech in the foreign language being studied before the State Qualification Commission on the topic of final qualification work. 
The technique of preparing a speech within the allocated 8 minutes and the accompanying presentation has been worked out in detail. But the situation of the transition to distance learning in connection with the pandemic situation forced us to make serious adjustments to the process of preparing both the oral speech itself and the presentation. In May 2020, for the first time, the defense of qualification works under the bachelor's program in a distance mode was passed at the Law Institute. An analysis of the organization of the preparatory stage of composing a speech for the defense in the online format, discussion with colleagues in the department and graduates of the final results of the defense of final qualification works for the bachelor's program confirmed the correctness of the main provisions of the language training of future specialists in the field of jurisprudence at the Department of Foreign Languages of the Law Institute of RUDN University:

- Creation of conditions to support the deepening and renewal of the acquired professional and linguistic communicative competences in changing conditions, taking into account socio-cultural characteristics;

- Formation of students' readiness to solve various legal conflicts and problems.

This is what contributes to the formation of the fundamental professional competencies of future specialists in the field of jurisprudence, which are manifested already at the stage of preparation for the defense of the final qualification work under the bachelor's program and in the process of the defense itself in a foreign language:

- Cognitive competence (formulation of a legal problem in a foreign language and application of relevant laws);

- Competence of analytical and critical thinking (the ability to solve legal problems on the basis of laws, formulate new goals; critically evaluate solutions, compare and analyze);

- Search competence (the ability to find and analyze information to solve a legal problem);

- Bibliographic competence (the ability to select material on legal topics);

- Media competence (using computer and communication skills to create a presentation).

Based on the listed competencies and the definition of skills that reveal their essence, the author of the study analyzed the algorithm for preparing oral speech for defense and the process of creating a presentation that accompanies a speech in an online form.

\section{LITERATURE REVIEW}

At the initial stage of the research, the author turned to the analysis of the literature review on the stated topic. Finding the best options for organizing the preparation of oral speech for the defense of the final qualifying work for the bachelor's program in the online format is an important component of the modern learning process in a professional university (Heckmann, V. et al., 2012). University teachers are unanimous in the fact that the components of the success of an oral presentation to members of the State Qualification Commission are thoughtful paragraphs of the text of the speech itself, a worthy review of the scientific advisor and an external review, as well as confident knowledge of the information contained in the final qualifying work (Lazarova, L. et al., 2019). The author of the study tried to find and analyze articles affecting the above positions by Russian and foreign experts (Bausch, K., 2000; Döring, N., 2003; Arnold, R., 2012; Ebner, M. et al., 2013).

The analysis of publications on the stated topic allowed the author of this study to conclude that at the moment linguodidactic approaches associated with the analysis of the algorithm for preparing for oral speech in defense of the final qualification work under the bachelor's program of future specialists in the field of jurisprudence in online format require further development with subsequent approbation.

\section{METHODOLOGY}

Formation of the concept of research structure, determination of the direction and structure of analysis, as well as the use of research methods were based on the literature review conducted by the author. Taking into account the results obtained on the research topic, the author put forward a hypothesis that the specifics of the preparation of oral speech for the defense of the final qualifying work in the distance depends primarily on a clearly developed scheme, which includes the following components:

- Formulation of the relevance of the declared topic for the defense;

- Concrete development of the very topic of qualification work; 
- Specifics in determining the subject and object of the research;

- Specifying the purpose of the oral presentation itself;

- Classification of the methods used to obtain the final results;

- Specifying the effectiveness of the research work done;

- The formulation of conclusions and provisions for the defense.

The basis of the materials of the study was the comparative data of the questionnaire and oral survey of the graduates of the bachelor's program of the last three years of study, who studied German at the Department of Foreign Languages of the Law Institute of the Peoples' Friendship University of Russia under the program "Translator in the field of professional activity" and who have passed the procedure for defending their final qualification work in German language both offline and remotely in May 2020. In the course of the study, the collected empirical results were used based on comparison methods, as well as the results of comparative and systemic analyzes. In order to confirm the validity of the collected material, the author of the study used a questionnaire and interview technique, followed by a discussion of the results obtained and the formulation of proposals for making the necessary adjustments to the software of the educational process at the Department of Foreign Languages of the Law Institute of the Peoples' Friendship University of Russia.

\section{RESULTS AND DISCUSSION}

In the middle of the 7th semester, the author of the study handed out questionnaires to students in order to identify the main difficulties in preparing for the defense of the final qualifying work in German. The need to collect data by the end of the semester and discuss them was dictated by the need to adjust the algorithm for preparing for oral defense in German.

In the process of processing the received answers, it was revealed that the least difficulty is the formulation of the relevance of the declared topic for defense $(20 \%)$. The problem with the formulation of concretization in determining the subject and object of the research carried out was noted by $75 \%$ of the students. Difficulties in specifying the purpose of the oral presentation itself and classifying the methods used to obtain the final results in German were noted by $80 \%$ and $63 \%$. $90 \%$ requested assistance in formulating the effectiveness of the research work done, and $59 \%$ needed support in formulating conclusions and provisions to be defended. The results of the survey and interviews formed the basis for the joint work of the author of the study with the supervisors of students from the main graduating departments and making adjustments to the training program for the oral defense of the final qualifying work in German.

Both groups of students (who passed the defense in offline and online format) noted the fact that a laconic, clearly and competently constructed speech in defense of the final qualifying work is the main component of all successful defense. Oral presentation, according to $83 \%$ of respondents, is a short message, consisting of the fundamental theses and the main conclusions of the qualification work. This helps undergraduate graduates $(91 \%)$ not only present the results of their scientific research at a high level, but also prepare for answers to questions from members of the qualification commission.

For the students who came to the defense in a distance format, one of the problems was the question of how to interest the audience through the camera to attract attention to their performance (89\%). The students were also worried about the time spent on presenting the main ideas, presenting the theoretical component and expressing their own opinion based on the analysis of the subject and object of research (72\%). For $66 \%$, it was important to correctly formulate conclusions and main proposals on the topic studied. And all these moments had to be clearly laid down in a time frame in a situation when the student is face to face in front of the camera and the teacher cannot give a visual signal about the need to strictly adhere to the time limit allotted for the performance, as is often the case in offline format.

Based on this new situation in the regime, all types of tasks used by the author of the study in working with law students under the bachelor's program in preparation for oral presentation in the process of defending the final qualifying work were adjusted taking into account the principle of pedagogical constructivism, the personality-activity approach and were integral in nature with a focus on the development of interrelated types of professional foreign language speech activity.

\section{CONCLUSION}

Taking into account the fact that the main methodological and didactic task of the teacher is to create conditions during classes in any format, in which students not only master the German language for professional purposes, but also the competence to use the acquired skills and abilities at the stage of 
defense of the final qualifying work in the chosen specialty in the field of jurisprudence, the academic program of the discipline "Translator in the field of professional activity" included tasks and exercises not only of a linguistic orientation, but also taking into account the training of such components as adherence to the time limit; detailing new factors at the end of the oral presentation of the research results, the ability to disguise, if necessary, the fact of not mentioning the previously planned details of the speech in the remote protection format. This was done taking into account both linguistic and psychological components.

At the beginning of the 8th semester of study, an individual training plan was drawn up with each graduate of the bachelor's program, which includes the following points in stages:

- Highlighting the main components of the points of the study, put on the slides of the presentation;

- Structuring of the selected material;

- Material design in diagrams and tables;

- Selection of lexical and grammatical material in the defense language (German);

- Comparison of the oral text of the speech with the material of the presentation slides;

- Rehearsal in front of the camera and virtual audience.

It was this approach that contributed to the fact that the majority (92\%) of those participating in the defense of graduation qualification works in a distance format coped with the task with the highest result.

The author of the study expresses gratitude to colleagues and students who took part in the survey and discussion of the features of preparation for the oral defense of the final qualification work (bachelor's degree) in German in the context of the transition to distance learning.

\section{ACKNOWLEDGMENT}

The publication has been prepared with the support of the RUDN University program under 5-100 Russian Academic Excellence Project.

\section{REFERENCE LIST}

Arnold, R. (2012). Ich lerne, also bin ich: Eine systematisch - konstruktivistische Didaktik. Heidelberg, CarlAuer.

Bausch, K. u.a. (Hrsg.) (2000). Interaktion im Kontext des Lehrens und Lernens fremder Sprachen: Arbeitspapiere der 20. Frühjahrskonferenz zur Erforschung des Fremdsprachenunterrichts. Tübingen: Narr

Döring, N. (2003). Sozialpsychologie des Internets. (2. Auflage). Hogrefe: Göttingen.

Ebner, M., Schön, S. (2013). Lehrbuch für Lernen und Lehren mit Technologien. (L3T). Berlin:epubli

Heckmann, V., Strasser, T. (2012). Von der technischen Komplexität hin zur didaktischen Vielseitigkeit - „3 Clicks-Edu-Apps“" zur Steigerung der Sprechkompetenz im Fremdsprachenunterricht. In: KoppKavermann, M. (Hrsg): zeitschrift für elearning, lernkultur und bildungstechnologie. E-Learning im Fremdsprachenerwerb. Innsbruck, Wien, Bozen: Studienverlag, S. 34-36

Lazarova, L., Kairova, F. (2019). Final qualifying work: bachelor's degree. INFRA-M Academic Publishing LLC. DOI: 10.12737/textbook_5c9c681d2d49b3.19788676 ISBN: 978-5-16-014585-3

Europäische Kommission, (2012). Digitale Agenda: Neue Strategie für ein sicheres Internet und bessere Online-Inhalte für Kinder und Jugendliche. Pressemitteilung. 